\title{
NILAI-NILAI EDUKATIF SYAIR GULUNG SEBAGAI UPAYA PENDIDIKAN KEBENCANAAN BERBASIS KOMUNITAS PADA MASYARAKAT MELAYU DI KABUPATEN KETAPANG KALIMANTAN BARAT
}

\author{
Muhammad Syaifulloh ${ }^{\bowtie}$, dan Basuki Wibowo
}

Program Studi Pendidikan Sejarah IKIP PGRI Pontianak

\begin{tabular}{l}
\hline Info Artikel \\
\hline Sejarah Artikel: \\
Diterima 20 Okt 2017 \\
Disetujui 18 Nov 2017 \\
Dipublikasikan Des 2017 \\
\hline Keywords: Syair Gulung, \\
Educative Values, Natural \\
Disasters, community \\
communities, and Malay \\
Ketapang, West \\
Kalimantan \\
\hline
\end{tabular}
\begin{abstract}
This research aims to know and describe about 1) background of Syair Gulung in Ketapang Malay society of West Kalimantan, 2) Educative values contained in Syair Gulung, 3) Potential of Syair Gulung as a community-based disaster education efforts in Ketapang Malay society. This research uses qualitative research method with form of stuck case study strategy. Sources of data used are informants, places and events, and documents. Data collection techniques used direct observation techniques, in-depth interviews, and document studies. The sampling technique used is purposive sampling. Data validity uses triangulation and data analysis techniques using interactive analysis techniques.

Syair Gulung is a typical Malay cultural art. The educational values that exist in the Syair Gulung can be developed as a tool of dissemination of disaster education which recently happened such as forest fire and flood. Natural disasters that occur in the Ketapang community can not be separated from the fading and shifting values of local wisdom that developed in the community. As a preventive form for the preservation of the natural environment, it reinvents the educational values implicit in Syair Gulung contributing greatly in the effort to preserve the nature of the disaster. Educational theories of local wisdom and disaster risk education are important in helping the realization of a disaster-conscious society. Community communities are highly effective targets for awareness of the importance of disaster education.
\end{abstract}

\begin{abstract}
Abstrak
Penelitian ini bertujuan untuk mengetahui dan mendeskripsikan tentang 1) latar belakang Syair Gulung di masyarakat Melayu Ketapang Kalimantan Barat, 2) Nilai-nilai edukatif yang terkandung dalam Syair Gulung, 3) Potensi Syair Gulung sebagai upaya pendidikan kebencanaan berbasis komunitas pada masyarakat Melayu Ketapang. Penelitian ini menggunakan metode penelitian kualitatif dengan bentuk strategi studi kasus terpancang. Sumber data yang digunakan yaitu informan, tempat dan peristiwa, dan dokumen. Teknik pengumpulan data menggunakan teknik observasi langsung, wawancara mendalam, dan studi dokumen. Teknik cuplikan (sampling) yang digunakan bersifat purposive sampling. Validitas data menggunakan triangulasi dan teknik analisa data menggunakan teknik analisis interaktif.

Syair Gulung merupakan seni budaya khas Melayu. Nilai-nilai edukatif yang ada dalam Syair Gulung dapat dikembangkan sebagai alat sosialisasi pendidikan kebencanaan yang akhir-akhir ini sering terjadi seperti kebakaran hutan dan banjir. Bencana alam yang terjadi di masyarakat Ketapang tidak terlepas dari memudar dan pergeseran nilai kearifan lokal yang berkembang dalam masyarakat. Sebagai bentuk preventif akan kelestarian lingkungan alam, maka memunculkan kembali nilai-nilai edukatif yang tersirat dalam Syair Gulung memberikan andil besar dalam upaya menjaga alam dari bencana. Teori pendidikan nilai-nilai kearifan lokal dan pendidikan resiko kebencanaan menjadi penting dalam usaha membantu terwujudnya masyarakat sadar bencana. Komunitas masyarakat menjadi sasaran yang sangat efektif dalam upaya penyadaran akan pentingnya pendidikan kebencanaan.
\end{abstract}

(C) 2017 Universitas Muria Kudus

\begin{tabular}{lr}
\hline Alamat korespondensi: & p-ISSN 2087-9385 \\
Program Studi Pendidikan Guru Sekolah Dasar & e-ISSN 2528-696X \\
Fakultas Keguruan dan Ilmu Pendidikan Universitas Muria Kudus & \\
Kampus UMK Gondangmanis, Bae Kudus Gd. L. 1t I PO. BOX 53 & \\
Kudus & \\
Tlp (0291) 438229 ex.147 Fax. (0291) 437198 & \\
E-mail: syaifullohm22@yahoo.com &
\end{tabular}




\section{PENDAHULUAN}

Bencana alam terjadi bisa secara tiba-tiba namun ada juga yang bisa dideteksi sebelumnya. Masyarakat harus melihat bencana alam dengan sikap bijak dan tepat. Terjadinya bencana alam yang tidak dapat diduga menjadikan masyarakat harus waspada akan kedatangan bencana alam. Berdasarkan Undang-undang Nomor 24 tahun 2007 Tentang Penanggulangan Bencana disebutkan bahwa kegiatan penanggulangan bencana tidak hanya menjadi tanggungjawab pemerintah saja, tetapi juga memerlukan keterlibatan dan peran serta masyarakat, sekolah, perguruan tinggi, dunia usaha, serta Lembaga Swadaya Masyarakat (LSM) lokal maupun Internasional.

Salah satu cara untuk meminimalisir dampak bencana yakni dengan memanfaatkan kearifan masyarakat. Pada dasarnya masyarakat memiliki kearifan untuk merespon apa yang terjadi dilingkungan. Semakin masyarakat mampu memanfaatkan kearifan lokal, maka masyarakat akan lebih waspada terhadap bencana serta masyarakat dapat lebih tanggap dalam mengambil sikap secara mandiri dan spontan.

Koentjaraningrat (2009) menyebutkan bahwa kearifan lokal masyarakat adalah cara dan praktik yang dikembangkan oleh sekelompok masyarakat yang berasal dari pemahaman mendalam akan lingkungan setempat, yang terbentuk di tempat tersebut secara turun-temurun dan membudaya. Berdasarkan perspektif kearifan budaya, perilaku alam termasuk didalamnya perilaku satwa maupun tanaman oleh masyarakat tradisional diamati sebagai fenomena alam yang dapat dijadikan petunjuk akan datangnya bencana alam. Cerita panjang dan kejadian alam menjadi sumber inspirasi dan selanjutnya memunculkan respon dalam bentuk perilaku untuk mengatasi gejolak alam, selanjutnya diceritakan dari generasi ke generasi sebagai pengetahuan dalam menyikapi alam dan perubahannya.

Dalam konteks penanggulangan bencana sampai saat ini, upaya-upaya yang dilakukan masyarakat dan para pemangku kepentingan belum optimal dan lebih banyak berupa pemberian bantuan pada era tanggap darurat dan rehabilitasi fisik pasca bencana. Adapun upaya efektif pada tahap pra bencana belum dilakukan dengan baik. Kesadaran pra bencana perlu dibangun dan diberdayakan, sehingga kelak masyarakat tidak lagi hanya menjadi korban bencana tetapi lebih menjadi sumberdaya penolong bagi dirinya sendiri dan lingkungan pada saat terjadi bencana.
Pada dasarnya masing-masing daerah sebenarnya memiliki pengetahuan dan kearifan lokal yang beragam dan berbeda bentuknya terhadap upaya penanggulangan bencana alam. Masyarakat Kabupaten Ketapang sebenarnya bisa memanfaatkan Syair Gulung sebagai media untuk sosialisasi pentingnya penanggulangan bencana alam. Kabupaten Ketapang sebagai suatu daerah yang mempunyai luas wilayah $35.809 \mathrm{~km}^{2}$ ( \pm $3.580 .900 \mathrm{ha})$ yang terdiri dari $33.209 \mathrm{~km}^{2}$ wilayah daratan dan $2.600 \mathrm{~km}^{2}$ wilayah perairan dan hampir duapertiganya merupakan hutan sangat resiko terhadap bencana alam.

Syair Gulung adalah salah satu tradisi lisan bersifat kesenian pementasan pada masyarakat Melayu yang ada di wilayah Kabupaten Ketapang. Syair dapat berfungsi sebagai alat komunikasi yang dapat digunakan untuk menyampaikan maksud secara lebih halus agar orang yang diajak bicara tidak merasa tersinggung walaupun maksud yang ingin disampaikan bernada kritikan atau protes terhadap sesuatu hal.

Isi syair memuat pesan moral. Tradisi lisan Syair Gulung merupakan bagian dari sastra lisan. Sastra lisan adalah kesusastraan yang mencakup ekspresi kesusastraan warga suatu kebudayaan yang disebarkan dan diturun-temurunkan secara lisan. Istilah syair gulung bagi masyarakat di Kabupaten Ketapang memiliki nama lain seperti Kengkarangan, Syair Layang dll. Di beberapa daerah hulu Kabupaten Ketapang terutama masyarakat dayak menyebut Syair Gulung dengan Syair Layang (Bamba, 1996).

Pemanfaatan Syair Gulung dalam pendidikan tanggap bencana dan pengurangan resiko bencana bisa dilakukan dalam masyarakat melalui komunitas-komunitas yang ada di masyarakat. Komunitas yang berkembang dalam masyarakat bisa berupa komunitas adat, komunitas pendidikan maupun komunitas seni. Sosialisasi dalam masyarakat bisa disisipkan pada saat perayaan adat maupun acara-acara lain yang berupa pertemuan masyarakat. Syair Gulung biasanya dibacakan pada acara tertentu, di situlah pesan tentang tanggap bencana bisa di sisipkan.

Hutan yang luas di wilayah Ketapang terdiri dari hutan alami, hutan adat dan hutan rakyat. Hutan rakyat sekarang sudah alih fungsi menjadi perkebunan karet dan sawit, bahkan sudah ada yang di eksplorasi untuk diambil bahan mineralnya (pertambangan). Pertambangan bauksit dan biji timah banyak dibuka di wilayah Kabupaten Ketapang terutama di daerah yang banyak hutan dan sepanjang Daerah Aliran Sungai (DAS) yang masih alami.

Syamsuni (1994) menyatakan Kabupaten ketapang juga memiliki hutan gambut yang sangat luas. Luas hutan gambut 267.051 hektar 
membentang dari barat laut dan selatan Taman Nasional Gunung Palung dan dari daerah pantai ke Kota Ketapang. Luasnya hutan gambut pada musim kemarau akan berdampak pada banyaknya titik api di wilayah ini.

Potensi bencana di wilayah Kabupaten Ketapang sangat banyak. Kebakaran hutan dan kabut asap menjadi bencana alam yang bersifat tahunan. Kebakaran hutan yang ada di wilayah Ketapang bisa terjadi karena kesengajaan maupun ketidaksengajaan. Faktor kesengajaan biasanya dilakukan oleh perusahaan sawit yang ingin cepat dan murah dalam membuka lahan. Kebakaran yang tidak sengaja biasanya dilakukan oleh masyarakat sekitar hutan. Baik yang dilakukan secara individu maupun kelompok. Kebakaran yang tidak disengaja biasanya terjadi ketika masyarakat yang tidak mengenal struktur tanah membakar hutan untuk membuka ladang tepat ditempat tanah gambut yang mudah terbakar sehingga tidak dapat di kendalikan.

Ave dan King (dalam Syamsuni, 1994: 129), mengemukakan bahwa tradisi berladang (siffing cultivation atau swidden) orang Dayak sudah dilakukan sejak zaman nenek moyang mereka merupakan sebagai mata pencaharian utama. Sellato (dalam Bamba, 1996), memperkirakan sistem perladangan yang dilakukan orang Dayak sudah dimulai dua abad yang lalu.

Tuduhan yang dialamatkan terhadap masyarakat Dayak sebagai perusak hutan tidaklah beralasan, hal ini karena dalam memanfaatkan hutan sebagai areal lading, peralatan yang digunakan hanyalah mengandalkan kapak dan parang. Berbeda dengan para pemegang Hak Pengelolaan Hutan (HPH) yang dimiliki perusahaan yang mampu memobilisasi banyak pekerja dan memanfaatkan teknologi tinggi bahkan untuk menutup biaya operasional mereka tidak segan melakukan pembakaran hutan.

Penelitian Meng-han (2014) menemukan bahwa dengan konsep permainan berbasis komputer, diharapkan masyarakat dapat berlatih untuk menyelamatkan diri dengan memprogram game mitigation di komputer masing-masing. Penelitian ini mengindikasikan bahwa upaya pendekatan modern tidak terlalu signifikan dalam upaya sosialisasi tanggap bencana. Dengan kata lain, asumsinya bahwa pendekatan lain yaitu menggunakan pendekatan sejarah lisan yang bersifat tradisional diharapkan mampu menjadi alat/media alternatif dalam sosialisasi pendidikan tanggap bencana dan sebagai pendekatan alternatif upaya preventif bencana alam melalui kearifan lokal masyarakat.

Nilai-nilai edukatif dalam Syair Gulung sebagai pendidikan kebencanaan berbasis komunitas di Kabupaten Ketapang sangat penting untuk diteliti. Nilai-nilai tersebut dapat dimanfaatkan sebagai media dan pesan pendidikan dalam mengupayakan kesadaran lingkungan dan mampu menciptakan suatu masyarakat yang peka dan tanggap terhadap bencana alam. Adanya pemanfaatan Syair Gulung ini diharapkan nantinya dapat meningkatkan kesadaran masyarakat Melayu Ketapang untuk lebih siap siaga dalam menghadapi bencana.

\section{METODE}

Penelitian ini menggunakan metode penelitian kualitatif dengan bentuk strategi studi kasus terpancang. Sumber data yang digunakan yaitu informan, tempat dan peristiwa, dan dokumen. Teknik pengumpulan data menggunakan teknik observasi langsung, wawancara mendalam, dan studi dokumen.

Teknik cuplikan (sampling) yang digunakan bersifat purposive sampling. Validitas data menggunakan triangulasi dan teknik analisa data menggunakan teknik analisis interaktif.

\section{HASIL DAN PEMBAHASAN}

\section{Sejarah Syair Gulung}

Syair Gulung pada awalnya merupakan sebuah bentuk karangan dari pujangga dan mubaligh Keraton Matan yang bertujuan menyampaikan pesan kepada raja. Sifat pembacaan syair yang teksnya yang selalu digulung dan digantung pada paruh burung kertas dipuncak kekayun (tempat nasi dari kayu biasanya dihiasi bunga telur untuk antaran pernikahan/sunatan), maka akhirnya disebut Syair Gulung.

Menurut cerita lisan yang berkembang di masyarakat Melayu terutama yang ada di Kabupaten Ketapang, Syair Gulung dipakai oleh para mubaligh yang datang ke Tanah Kayong sebagai alat dalam menyebarkan dakwah Islam. Syair Gulung merupakan salah satu bentuk lisan namun setelah masuknya Islam maka kerajaan Tanjungpura mulai terbuka dengan dunia luar dan mulai mengenal aksara, selain itu Syair Gulung mulai ditulis di atas kertas atau apapun pada masa itu untuk memudahkan sang pengarang dalam menyampaikan syairnya.

Menurut sumber dari para pemuka adat Melayu yang tergabung dalam Majelis Adat Budaya Melayu (MABM), ada beberapa versi tentang sejarah keberadaan Syair Gulung. Kebanyakan dari mereka menyepakati bahwa Syair Gulung pada dasarnya sudah ada di Tanah Kayong Tanjung Pura pada saat Islam pertama kali. Islam masuk dibawa oleh Syekh Hasan Al- 
Qadrie atau dibawa oleh para muballigh dari bangsa Melayu yang datang ke Tanah Kayong yang kemudian dilanjutkan oleh Syekh Magribi.

Ada sebagian kecil masyakatat yang meyakini bahwa Syair Gulung pada dasarnya sudah ada jauh sebelum masuknya Islam, dikarenakan bangsa Melayu merupakan bangsa yang gemar akan sastra, dan sastra merupakan bagian yang tidak terpisahkan dari kehidupan orang-orang Melayu. Pada jaman keemasan kerajaan Tanjung Pura seni sastra berkembang sangat pesat.

Pada setiap upacara yang dilaksanakan oleh Raja atau Pangeran atau pejabat kerajaan lain serta para kepala wilayah yang terendah selalu ada saja penyair yang melantunkan Syair Gulung. Selanjutnya penduduk negeripun ikutikutan membacakan Syair Gulung pada upacara perkawinan, sunatan dan lain-lain.

Pada awalnya syair hanya dilantunkan menurut perasaan pensyair saja. Masyarakat Melayu telah mengenal Syair Gulung sebagai suatu karangan yang digunakan pada saat diadakannya proses adat Melayu, pernikahan, khataman dan sebagainya. Syair Gulung sebagai bagian dari seni budaya yang ada di Ketapang, sangat erat kaitannya dengan kehidupan masyarakat. Disini masyarakat Ketapang mengutamakan Syair Gulung sebatas pada seni hiburan saja.

Saat ini Syair Gulung merupakan syair kontemporer yang bercerita untuk suatu acara dan pada suatu waktu tertentu. Syair ini hanya untuk sekali pakai saja. Syair Gulung untuk khataman tidak bisa dibacakan untuk upacara Maulid Nabi.

Penulis syair gulung sendiri tak pernah belajar dengan sungguh-sungguh pada penyair sebelumnya. Tak ada pakem tertentu dalam membuat Syair Gulung, asal bisa indah dibaca dan masuk lagunya. Penulis syair gulung hanya berbekal bakat saja. Dengan demikian Syair Gulung yang berkembang saat ini lebih pada syair kontemporer yang habis sekali pakai itu. Hal ini untuk membedakan dengan Syair Gulung tradisional. Dalam kehidupan masyarakat Melayu Ketapang, Syair Gulung sudah merupakan bagian dari tradisi dan syair merupakan ekspresi pikiran dan perasaan yang dituturkan dalam bentuk seni pertunjukan.

\section{Nilai-nilai Edukatif Syair Gulung Untuk Pendidikan Kebencanaan}

Syair Gulung yang berkembang dalam masyarakat Melayu Ketapang pada awalnya merupakan media dalam penyebaran agama Islam. Syair Gulung memiliki nilai-nilai sebagai petunjuk-petunjuk umum yang telah berlangsung lama yang mengarahkan tingkah laku dan kepuasan dalam kehidupan sehari-hari (Sulaiman, 1992). Nilai-nilai eduktif yang terkandung dalam Syair Gulung yang dapat dijadikan sebagai media untuk pendidikan kebencanaan, antara lain

1. Nilai Kebersamaan/GotongRoyong

Nilai-nilai ini termasuk suka menolong, sikap solidaritas diri yang kuat serta mencerminkan sikap yang memegang teguh adat serta warisan budaya yang harus dijaga dan dilestarikan sebagai impementasi ajaran-ajaran Islam Melayu Ketapang sebagai satu kesatuan sistem. Nilai gotong-royong akan sangat berguna bagi masyarakat dalam upaya tanggap bencana.

Hamdan M. Amin dalam judul Deklarasi Lembaga Adat Melayu Serantau dan Rumah Adat Melayu Dalam Syair, menjelaskan tentang pentingnya bersatu dan gotong royong.

\section{Kalau kita kukuh bersatu Bulatkan seperti bolanya batu Tidak mudah ditendang ke sini situ Allah Hu Akbar, InsaAllah, Allah membantu \\ Jangan kita berpecah belah Kalau bertanding pastilah kalah Karena kekompakan terpilah-pilah Peluang terbuka mencari celah}

2. Nilai peduli dan lingkungan

Kepedulian terhadap lingkungan salah satu nilai dari Syair Gulung yang biasanya dibacakan pada setiap pementasan syair. Ada beberapa contoh syair yang dibuat oleh masyarakat Melayu di Kabupaten Ketapang yang berisi tentang nasehat untuk melestarikan alam sekitar. Berikut ini salah satu contoh Syair Gulung yang berisi nasehat untuk mencintai alam sekitar.

Ilegal logging perlu dibasmi Agar hutan kembali lestari

Kami bertanya pada bapak polisi

Benarkah tak terima sopoi atau komisi?

Tim-tim pemberantasan banyak dibentuk Mengejar perambah hutan hingga tersantuk

Yang di pelabuhan dudok mengantuk Kayu lewat ditarik tackboot

Perambahan hutan makin meriah Hutan lindung ikut dirambah Mengatasinya sebenarnya mudah Cukup menangkap si tukang tadah 
Nilai cinta lingkungan diajarkan dalam bentuk syair yang berisi bagaimana sakral dan terhormatnya sebuah tempat seperti sumber air, mata air, hutan dan sungai. Penyair akan menyisipkan mitos-mitos yang berkembang di masyarakat agar masyarakat mengetahui pentingnya sebuah tempat. Hal ini seperti dicontohkan dalam Syair Gulung karya Hamdan M. Amin, seperti di bawah ini

\section{Negeri Baru desa misteri \\ Makam keramat masih lestari \\ Bukti sejarah zaman bahari \\ KerajaanTanjungpura awal berdiri \\ Pemandangan indah di sungai Pawan \\ Tempat memukat ikan Biawan \\ Sebagai lokasi wisata Bengawan \\ Sungai Sentapang kerdan rawan}

Dalam karyanya Hamdan M. Amin menyatakan bahwa sungai sentapang kerdanrawan, hal ini di dasarkan pad amitos yang berkembang pada masyarakat local Ketapang yang menjelaskan bahwa sungai itu terkenal keaangkerannya. Mitos yang berkembang pada masyarakat tentang keangkeran sungai pada dasarnya akan berdampak pada masyarakat akan hati-hati dalam memanfaatkan sungai terutama sungai pawan yang merupakan sungai terbesar di Kabupaten Ketapang.

Masyarakat tidak mengeksploitasi sungai untuk kepentingan komersial seperti mendirikan perusahaan pertambangan dipinggir sungai pawan. Adanya mitos yang pada sungai pawan akan berdampak pada terjaganya sungai dari kerusakan dan bencana banjir, terutama yang di timbulkan oleh manusia. Nilai-nilai yang terkandung dalam Syair Gulung sedemikian luas dan banyak dan member citra yang positif. Syair yang dibuat dengan tujuan dan maksud tertentu dibuat sedemikian rupa dengan harapan ada pesan yang tersalurkan dengan baik tanpa ada halangan yang berat.

Syair ini berfungsi sebagai nasehat dan dakwah pendidikan terutama nilai-nilai Islam yang syarat akan nilai edukatif atau pendidikan. Pendidikan adalah dasar kemajuan dan kesempurnaan masyarakat Melayu Ketapang Kalimantan Barat.

\section{Peran Komunitas Dalam Pendidikan Kebencanaan Pada Masyarakat Melayu Di Kabupaten Ketapang Kalimantan Barat \\ Syair Gulung masyarakat melayu} Ketapang, dapat dijadikan sebagai media sebagai pendidikan kebencanaan terutama dalam upaya pengurangan resiko bencana (PRB). Nilai-nilai yang terkandung dalam tradisi lisan Syair
Gulung terutama nilai cinta lingkungan dan gotong-royong bisa menggugah kesadaran masyarakat tentang perlunya upaya PRB. Masyarakat dan pemerintah harus memiliki keinginan yang sama dalam upaya pencegahan bencana alam di Ketapang terutama banjir dan kebakaran hutan.

Komunitas masyarakat yang ada di Ketapang dapat digolongkan menjadi komunitas hoby, komunitas daerah maupun komunitas suku dan agama. Banyaknya komunitas yang tersebar di wilayah ketapang merupakan salah satu aset yang dapat dimanfaatkan sebagai ajang untuk sosialisasi pendidikan kebencanaan. Komunitas memiliki basis masa yang jelas dan loyalitas yang kuat diantara anggota anggotanya. Masyarakat Melayu di Ketapang memiliki beberapa komunitas seperti komunitas pecinta Syair Gulung, komunitas pemuda melayu, Majelis adat budaya Melayu dan serumpun Melayu Kendawangan.

Pendidikan kebencanaan pada masyarakat Melayu bisa dengan melibatkan komunitas komunitas yang ada di Ketapang. Pendidikan kebencanaan dengan melibatkan masyarakat terutama komunitas-komunitas yang ada dapat dilakukan dengan berbagai cara, salah satunya dengan media seni yaitu seni pementasan Syair Gulung. Pendidikan kebencanaan dengan melibatkan komunitas masyarakat dilakukan dalam bentuk kegiatan-kegiatan penyadaran tentang pentingnya upaya pengurangan resiko bencana.

Upaya pendidikan PRB dilakukan dengan cara memberi pemahaman pada masyarakat tentang bagaimana bencana alam, bagaimana sejarah bencana alam di wilayahnya dan bagaimana pola pola penanganan bencana. Sosialisasi tentang hal tersebut harus bersifat konsisten, hal ini dikarenakan datangnya bencana alam tidak dapat diduga.

Masyarakat akan terbiasa melakukan sesuatu apabila dilakukan secara terus-menerus. Pedidikan kebencanaan juga harus dilakukan secara terus-menerus, berkala dan konsisten. Komunitas masyarakat adalah lembaga masyarakat yang di rasa tepat untuk pendidikan seperti ini, hal ini di karenakan dalam komunitas pasti sudah ada komitmen bersama antar anggota.

Pendidikan kebencanaan pada komunitas akan sesuai dan mengena apabila dilakukan tidak dengan cara yang formal. Syair Gulung bisa dijadikan sebagai media untuk pendidikan kebencanaan dalam masyarakat.

Nilai-nilai Syair Gulung bisa diajarkan dalam komunitas dengan cara seni pertunjukan, hal ini akan berdampak baik pada lingkungan 
karena mudah dipahami dan dimengerti pesanpesan tentang kebencanaan. Nilai-nilai cinta lingkungan dan gotong royonng yang ada dalam Syair Gulung bisa juga dijadikan sebagai sumber dalam pendidikan kebencanaan berbasis komunitas masyarakat.

\section{SIMPULAN}

Syair Gulung merupakan tradisi lisan yang berkembang pada masyarakat Melayu Ketapang yang memiliki potensi dalam usaha preventif bencana alam. Nilai-nilai yang ada dalam Syair Gulung dapat dijadikan sebagai pendidikan kebencanaan.

Nilai-nilai edukatif dalam Syair Gulung seperti religius, peduli sosial, peduli lingkungan, toleransi, tangung jawab dan kreatif member pelajaran sejak dini tentang pengembangan pendidikan kebencanaan. Revitalisasi nilai-nilai Syair Gulung sangat penting dalam konteks pengembangan gerakan sadar budaya, sadar lingkungan serta sadar pendidikan kebencanaan.

Pendidikan kebencanaan dengan melibatkan komunitas masyarakat sangat penting. Komunitas masyarakat memiliki peran penting karena mereka memiliki basis massa yang nyata dan loyal. Seni pertunjukan, dalam hal ini Syair Gulung akan menjadi media yang efektif dalam menyampaikan pesan pesan terutama tentang pengurangan resiko bencana alam. Nilai-nilai yang terkandung dalam Syair Gulung, terutama nilai cinta lingkungan dan gotong-royong dapat digunakan sebagai sumber dan media pendidikan kebencanaan yang melibatkan komunitas masyarakat.

\section{DAFTAR PUSTAKA}

Bamba, John. 1996. "Pengelolaan Sumber Daya Alam: Menurut Budaya Dayak Dan Tantangan Yang Di Hadapi”. Jurnal Kalimantan Review 15 (V).

Illich, Ivan. 1994. "Deschooling Society". London: Caldar \& Boyars Ltd.

Koentjaraningrat. 2009. "Pengantar Ilmu Antropologi”. Jakarta: Rineka Cipta.

Maman, Rachman. 2015. Lima Pendekatan Penelitian. Yogyakarta: Magnum Pustaka Utama.

Meng-Han Tsai , Ming-Chang Wen, Yu-Lien Chang, Shih-Chung Kang. 2014. Gamebased education for disaster prevention. London.
Mulyana, Rohmat. 2004, Mengartikulasikan Pendidikan Nilai. Bandung: Alfabeta.

Moleong, Lexy J. 2012. Metodologi Penelitian Kualitatif. Bandung: PT Remaja Rosdakarya.

Sulaiman. 1992. "Struktur Sosial dan Nilai Budaya Masyarakat Pedesaan". Yogyakarta: APD.

Suminto, A, Sayuti. 2016. Menuju Situasi Sadar Budaya: Antara yang lain dan Kearifan Lokal. Dalam http://www.semipalar.net, diakses pada 24 Mei 2016.

Syamsuni, Arman. 1994. "Perladangan Berpindah Dan Kedudukannya Dalam Kebudayaan Suku-Suku Dayak Di Kalimantan Barat”. Makalah disajikan dalam Dies Natalis XXX dan Lustrum VI Universitas Tanjungpura Pontianak

Undang-undang Nomor 24 Tahun 2007 Tentang Penanggulangan

Bencana. 